69. Smith, R. T.: Tumor-specific immune mechanisms. N. Engl. J. Med., 278: 1207, $1268,1326(1968)$.

70. Smith, R. T. Possibilities and problems of immunologic intervention in cancer. N. Engl. J. Med., 287: 439 (1972)

71. Soborg, M. and Bendixen, G.: Human lymphocyte migration as a parameter of hypersensitivity. Acta. Med. Scand., 181: 247 (1967)

72. Solowey, A. C., and Rapaport, F. T.: Immunologic responses in cancer patients. Surg. Gynecol. Obstet., I21: 756 (1965).

73. Sparks, F. C., Silverstein, M. J., Hunt, J. S., Haskell, C. M., Peck, Y. H., and Morton, D. L.: Complications of BCG immunotherapy in patients with cancer N. Engl. J. Med. 289: 827 (1973)

74. Stewart, T. H. M.: The presence of delayed hypersensitivity reaction in patients toward cellular extracts of their malignant tumors. I. The role of tissue antigen nonspecific reactions of nuclear material, and bacterial antigen as a cause for this phenomenon. Cancer, 23: 1368 (1969).

75. Stjernswärd, J., Almgard, L. E., Franzen, S., von Schreeb, T., and Waldström, L. B.: Tumor destructive cellular immunity to renal carcinoma. Clin. Exp. Immunol., 6: 963 (1970).

76. Stjernswärd, J., and Clifford, P.: Tumor distinctive cellular immune reactions against autochthonous cancer. In: L. Severi: Immunity and Tolerance on Oncogenesis. Perugia, Div. Cancer Res., p. 749 (1970)

77. Stjernswärd, J., Clifford, P., and Singh, S., and Svedmyr, E.: Indications of cellular immunological reactions against autochthonous tumor in cancer patients studied in vitro. E. Afr. Med. J., 7: 484 (1968)

78. Stjernswärd, J., Johansson, B., Svedmyr, E., and Sundblad, R.: Indication of tumor-specific cellbound immunological reactivity and depressed general reactivity in a pair of twins. Clin. Exp. Immunol, 6: 429 (1970).

79. Straus, E., Vernace, S., Janowtiz, H., and Paronetto, F.: Migration of peripherat leukocytes in the presence of carcinoembryonic antigen: Studies in patients with chronic inflammatory diseases of the intestines and carcinoma of the colon and pancreas. Proc. Soc. Exp. Biol. Med., 148: 494 (1975).

80. Thomas, L.: In: H. S. Lawrence: Cellular and Humoral-Aspects of Hypersensitivity States, p. 529 (H. Hoeber, New York, 1959).

81. Tripodi, D., Parks, L. C., and Brugmans, J.: Drug-induced restoration of cutaneous delayed hypersensitivity in anergic patients with cancer. N. Engl. J. Med., 289: 354 (1973)
82. Vanky, F., Stjernswärd, J., and Nilsonne, V.: Cellular immunity to human sarcoma. J. Natl. Cancer Inst. 46: 1145 (1971)

83. Webster, D. J. T., and Hughes, L. E.: Levamisole. Lancet $i: 389$ (1975).

84. Wara, D. W., Goldstein, A. L., Doyle, N. E.. and Amman, A. J.: Thymosin activity in patients with cellular immunodeficiency. N. Engl. J. Med., 292: 70 (1975).

85. Ward, P. A., Remold, H. G., and David, J. R.: Leukotactic factor produced by sensitized lymphocyte. Science I63: 1079 (1969).

86. Ward, P. A., Remold, H. G., and David, J. R.: The production of antigenstimulated lymphocytes of a leukotactic factor distinct from migration inhibitor factor. Cell Immunol. I: 162 (1970).

87. Watkins, E., Jr., Ogata, Y., Anderson, L. L., Watkins, E., III, and Waters, M. F. Activation of host lymphocytes cultured with cancer cells heated with neuraminidase. Nature New Biol., 231: 85 (1971)

88. Wheelock, E. F.: Interferon-like virus inhibitor induced in human leukocytes by phytohemagglutinin. Science, 149: 310 (1965).

89. Wolberg, W. H., and Goelzer, M. L.: In vitro assay of cell-mediated immunity in human cancer. Definition of leukocyte migration inhibitory factor. Nature, 229: 632 (1971)

90. Wybran, J., Levin, A. S., Spitler, L. E., and Fudenberg, H. H.: Rosette forming cells, immunologic deficiency disease and transfer factor. N. Engl. J Med. 288: 710 (1973)

91. Zaldivar, N M. Papageorgiou, P. S. Kaffe, S., and Glade, P. R.: The use of transfer factor in a patient with agammaglobulinemia. Pediat. Res. 9: 541 (1975).

92. This paper was part of the American Pediatric Society Symposium on Immunologic and Genetic Aspects of Cancer.

93. This work was supported in part by Research Grant IR01 All2475 from the National Institutes of Allergy and Infectious Diseases; Contract no. NO1CB-33912 from the National Cancer Institute of the National Institutes of Health, United States Public Health Service; and by a grant from the Goldhirsch Foundation, New York

94. Requests should be addressed to: P. R. Glade, M.D., Professor of Pediatrics, Division of Pediatric Infectious Disease and Immunology, University of Miami School of Medicine, P.O. Box 520875, Miami, Fla. 33152 (USA).

95. Accepted for publication October 31, 1975

\title{
Electrolyte Abnormalities in Very Low Birthweight Infants
}

\author{
G. M. DAY, 1. C. RADDE, (32) J. W. BALFE, AND G. W. CHANCE \\ Research Institute, Divisions of Neonatology, Endocrinology, and Nephrology, The Hospital for Sick \\ Children; Department of Paediatrics, University of Toronto, Toronto, Ontario, Canada
}

\section{Extract}

In 30 very low birth weight (VLBW) infants, fed a commercial formula at $200 \mathrm{ml} / \mathrm{kg} / 24 \mathrm{hr}$ to provide $160 \mathrm{cal} / \mathrm{kg} / 24 \mathrm{hr}$, hyponatremia (plasma $\mathrm{Na}^{+}<130 \mathrm{mEq}$ /liter) occurred in 23 patients ( 14 appropriate for gestational age (AGA), 9 small for gestational age (SGA)) between the ages of 2 and 6 weeks. In five infants the hyponatremia recurred even after adequate correction of the deficit. Calcium supplementation given to 14 of the infants did not affect the incidence or severity of hyponatremia. In AGA infants, the hyponatremia was more severe than in SGA babies.

Hyperkalemia (plasma $\mathrm{K}^{+}>5.5 \mathrm{mEq} /$ liter) was more common in AGA than in SGA infants (16/17 AGA, 7/13 SGA). Decrease in mean plasma chloride concentrations was proportionate to the decrease in mean $\mathrm{Na}^{+}$

Urinary $\mathrm{Na}^{+}$averaged $1.0 \mathrm{mEq} / \mathrm{kg} / 24 \mathrm{hr}$ and was equal between groups during the first balance at a mean age of 18 days. In subsequent balances it appeared to decrease more rapidly in noncalcium-supplemented than in calcium-supplemented infants, but the difference was not significant $(P<0.1)$. Fecal excretion of $\mathrm{Na}^{+}$ did not differ between groups.

Symptoms were unrelated to the degree of hyponatremia or hyperkalemia and were nonspecific.

Hyponatremia in A GA infants occurred in $50 \%$ of instances when growth was $\leq 0.75 \mathrm{~cm} /$ week, whereas it occurred in only $13.5 \%$ of infants when growth exceeded $1 \mathrm{~cm} /$ week $(P<0.01)$. A similar trend in SGA infants was not statistically significant $(P<0.2)$.

\section{Speculation}

The hyponatremia in VLBW infants between weeks 2 and 6 of postnatal age is due to a combination of high urinary losses relative to plasma levels, insufficient intake due to the relatively low $\mathrm{Na}^{+}$ content of certain infant formulas and coprecipitation of $\mathrm{Na}^{+}$in 
bone when length growth is rapid. Renal compensatory mechanisms for increased $\mathrm{Na}^{+}$retention develop after prolonged feeding of low $\mathrm{Na}^{+}$formula to VLBW infants.

There are few reports of plasma $\mathrm{Na}^{+}$concentrations in "healthy" VLBW infants after the immediate neonatal period $(19-21)$, moreover these refer to few infants of birthweight $<1.3$ $\mathrm{kg}(8)$.

We have shown previousiy that VLBW infants fed with standard formula develop marked calcium deficiency within a few weeks of birth (6). An incidental and disturbing finding in many of these infants was that of hyponatremia and hyperkalemia, usually between the second and sixth week of life.

We wish to report the electrolyte changes in these infants and discuss possible contributory factors.

\section{PATIENTS AND METHODS}

\section{PATIENTS AND PROCEDURES}

For the purposes of this study hyponatremia and hyperkalemia were defined arbitrarily as plasma $\left|\mathrm{Na}^{+}\right|<130 \mathrm{mEq} /$ liter and as plasma $\left[\mathrm{K}^{+}\right\rfloor>5.5 \mathrm{mEq} /$ liter.

Thirty VLBW infants were studied, none of them seriously ill during the study period. The infants were assessed for gestational age (7) and assigned to pairs within birthweight categories as described in a previous paper (6). The infants were admitted to the study when they were able to consume at least $80 \%$ of the desired formula intake $(200 \mathrm{ml} / \mathrm{kg} / 24 \mathrm{hr})$, which was achieved at an average age of 18 days. The study terminated when infants reached $1.8 \mathrm{~kg}$ body weight. All infants were fed SMA (27), $200 \mathrm{ml} / \mathrm{kg} / 24$ $\mathrm{hr}$ to provide $160 \mathrm{cal} / \mathrm{kg} / 24 \mathrm{hr}$ and were given $0.3 \mathrm{ml}$ of a multivitamin preparation (28) daily.

One member of each pair, assigned to group $B$, received supplemental calcium $(147 \mathrm{mg} / \mathrm{kg} / 24 \mathrm{hr})$ as calcium lactate in addition to the $110 \mathrm{mg} \mathrm{Ca} / \mathrm{kg} / 24 \mathrm{hr}$ contained in the formula. Acid-base status was maintained within 1 SD of normal mean for infants of this age (2) by oral $\mathrm{NaHCO}_{3}$ as necessary (6).

Venous or arterialized heel-prick blood was obtained twice weekly for determination of plasma electrolytes. Blood for $\mathrm{K}^{+}$ determination was processed and analyzed promptly and was not hemolyzed.

Three-day stool and 24-hr urine collections for electrolyte measurement were obtained as described previously (6). From these data net balances (excluding losses in sweat) were calculated for $\mathrm{Na}^{+}$and $\mathrm{K}^{+}$.

\section{CHEMICAL. METHODS}

$\mathrm{Na}^{+}$and $\mathrm{K}^{+}$concentrations were determined in plasma, urine feces, and formula with standard flame spectrophotometric techniques (29). Plasma $\mathrm{Cl}^{-}$was determined by amperometric-coulometric titration (5).

\section{RESULTS}

\section{PLASMA ELECTROLYTES}

Because no statistically significant differences were observed between nonsupplemented (group $A$ ) and calcium-supplemented groups (group $B$ ), the plasma values were pooled. Values obtained within $48 \mathrm{hr}$ of $\mathrm{Na}^{+}$supplementation in any form were excluded.

Plasma $\mathrm{Na}^{+}, \mathrm{K}^{+}$, and $\mathrm{Cl}^{-}$concentrations on admission to the hospital, at the start of the study, and at weekly intervals thereafter are shown in Figure 1. Mean plasma $\mathrm{Na}^{+}$and $\mathrm{K}^{+}$concentrations were normal $\left(\mathrm{Na}^{+} 135-145 \mathrm{mEq} /\right.$ liter; $\mathrm{K}^{+} 3.5-5.0 \mathrm{mEq} /$ liter $)(1)$ on admission, usually on the first day of life. When the infants entered the study the plasma $\mathrm{Na}^{+}$had already decreased significantly in all instances; mean values declined further, the lowest occurring between week $l$ and week 3 of the study (postnatal age
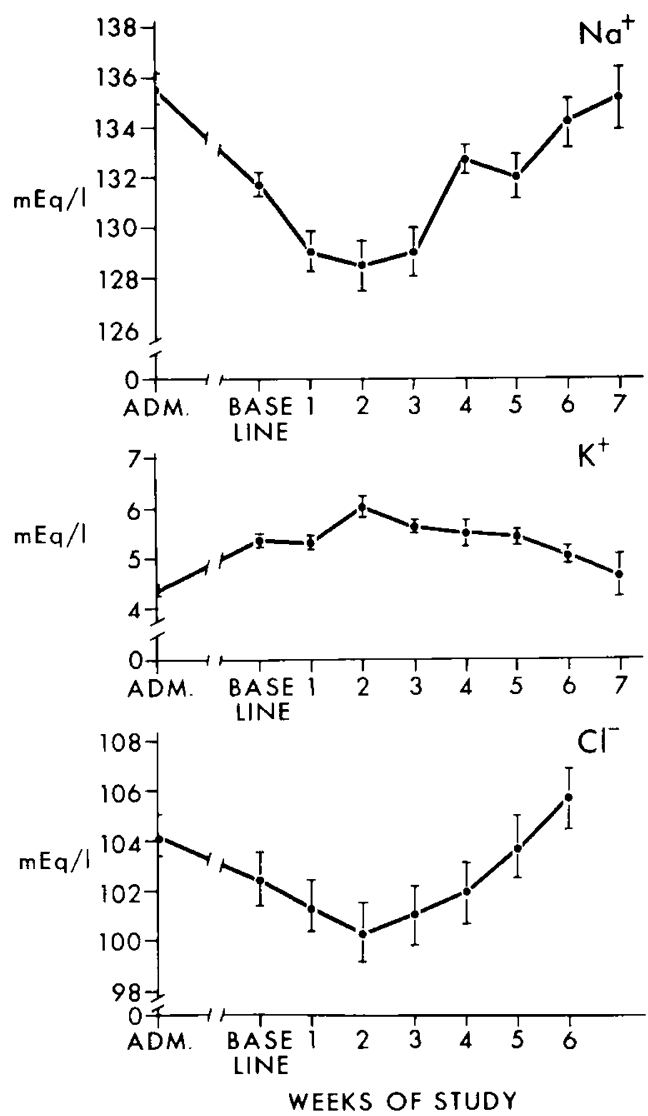

Fig. 1. Plasma $\mathrm{Na}^{+}, \mathrm{K}^{+}$, and $\mathrm{Cl}^{-}$concentrations. $A d m$ : admission specimen; baseline specimen at a mean age of 18 days. Results from individual patients have been averaged each week and from these total means \pm 1 SEM have been calculated.

3-5 weeks). During the study, hyponatremia occurred in 23 of the 30 patients. Table 1 shows the number of infants in each gestational age and treatment category and the severity of episodes of electrolyte abnormalities. There was no difference in the frequency and severity of hyponatremia between groups $A$ and $B$, but lowest values were observed in AGA infants. In five of the infants the hyponatremia recurred despite apparently adequate therapy for the deficit.

The mean plasma $\mathrm{K}^{+}$concentration was significantly higher at the beginning of the study at 18 days of age than on admission to hospital (Fig. 1) $(P<0.01)$. Hyperkalemia occurred in 23 patients (16 AGA, $7 \mathrm{SGA}$ ). The incidence of hyperkalemic episodes was similar in Groups $A$ and $B$. Individual values were as high as 8.5 $\mathrm{mEq} /$ liter.

Despite the apparent inverse relationship of mean plasma $\mathrm{Na}^{+}$ and $\mathrm{K}^{+}$concentrations (Fig. 1), no significant correlation was found on analysis of results for individual patients. The predominant electrolyte pattern in AGA infants was hyperkalemia with normal plasma $\left[\mathrm{Na}^{+}\right]$. In the 10 of $13 \mathrm{SGA}$ infants with electrolyte abnormalities, hyponatremia with or without hyperkalemia predominated.

Changes in mean plasma chloride values paralleled plasma sodium values. Although individual values were lower during hyponatremic episodes, the lowest plasma $\mathrm{Na}^{+}$value was not necessarily associated with the lowest plasma chloride concentration. Episodes of hypochloremia (plasma $\mathrm{Cl}^{-}<95 \mathrm{mEq} /$ liter were infrequent. The lowest value observed was $92 \mathrm{mEq} /$ liter.

\section{ELECTROLYTE INTAKE AND OUTPUT}

The results of $\mathrm{Na}^{+}$and $\mathrm{K}^{+}$intake and output measurements are shown in Figures 2 and 3. Urinary $\mathrm{Na}^{+}$excretion was initially similar in groups $A$ and $B$ and averaged $1 \mathrm{mEq} / \mathrm{kg} / 24 \mathrm{hr}$ at 2-3 
Table 1. Incidence and severity of hyponatremia and hyperkalemia ${ }^{1}$

\begin{tabular}{|c|c|c|c|c|c|c|}
\hline & \multirow{2}{*}{$\begin{array}{l}\text { No. pa- } \\
\text { tients }\end{array}$} & \multirow{2}{*}{$\begin{array}{l}\text { No. pa- } \\
\text { tients } \\
\text { with } \\
\text { hypona- } \\
\text { tremia }\end{array}$} & \multicolumn{4}{|c|}{$\begin{array}{l}\text { Episodes of hyponatremia } \\
\text { (plasma } \mathrm{Na}^{+}, \mathrm{mEq} / \text { liter) }\end{array}$} \\
\hline & & & Total & $125-129$ & $120-124$ & $<120$ \\
\hline \multicolumn{7}{|l|}{ Group A } \\
\hline $\mathrm{AGA}$ & 9 & 7 & 17 & 11 & 4 & 2 \\
\hline SGA & 7 & 6 & 11 & 10 & 1 & \\
\hline \multicolumn{7}{|l|}{ Group B } \\
\hline $\mathrm{AGA}$ & 8 & 7 & 13 & 7 & 3 & 3 \\
\hline SGA & 6 & 3 & 14 & 11 & 1 & 2 \\
\hline \multirow[t]{3}{*}{ Total } & 30 & 23 & 55 & 39 & 9 & 7 \\
\hline & \multirow{2}{*}{$\begin{array}{l}\text { No. pa- } \\
\text { tients }\end{array}$} & \multirow{2}{*}{$\begin{array}{c}\text { No. pa- } \\
\text { tients } \\
\text { with } \\
\text { hyper- } \\
\text { kalemia }\end{array}$} & \multicolumn{4}{|c|}{$\begin{array}{l}\text { Episodes of hyperkalemia } \\
\text { (plasma } \mathrm{K}^{+}, \mathrm{mEq} / \text { liter) }\end{array}$} \\
\hline & & & Total & $5.6-6.0$ & $6.1-6.5$ & $>6.5$ \\
\hline \multicolumn{7}{|l|}{ Group A } \\
\hline AGA & 9 & 9 & 28 & 13 & 6 & 9 \\
\hline $\mathrm{SGA}$ & 7 & 3 & 9 & 2 & 4 & 3 \\
\hline \multicolumn{7}{|l|}{ Group B } \\
\hline $\mathrm{AGA}$ & 8 & 7 & 19 & 9 & 5 & 5 \\
\hline SGA & 6 & 4 & 10 & 5 & 1 & 4 \\
\hline Total & 30 & 23 & 66 & 29 & 16 & 21 \\
\hline
\end{tabular}

${ }^{1} \mathrm{AGA}$ : appropriate for gestational age; SGA: small for gestational age.

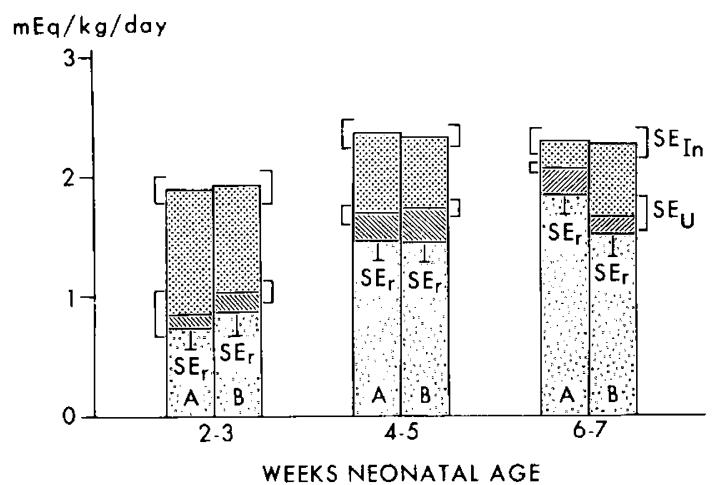

Fig. 2. Sodium intake and output, excluding losses in sweat (in milliequivalents per $\mathrm{kg}$ per $24 \mathrm{hr}$ ). Intake is plotted upwards from baseline: $\mathrm{SE}_{1 n}: \pm \mathrm{SE}$ of intake. $\mathrm{E}:$ urinary $\mathrm{Na}^{+}$excretion; $\mathrm{SE}_{U}: \pm \mathrm{SE}$ of urinary excretion. $\mathbb{N}$ : fecal $\mathrm{Na}^{+}$excretion. standard error of net retention. None of the differences between groups is statistically significant.

weeks postnatal age. Subsequently, it decreased more rapidly in nonsupplemented than in calcium-supplemented infants, but the difference just failed to reach significance $(P<0.1)$. Fecal excretion of $\mathrm{Na}^{+}$did not differ between groups $A$ and $B$, and there was an insignificant decrease with increasing age. Fecal excretion of $\mathrm{Na}^{+}$did not exceed $20 \%$ of intake, the mean being $<10 \%$ during the second and third balance. Mean net $\mathrm{Na}^{+}$retention increased with age, more so in SGA than in AGA infants, but equally in calcium-supplemented and in nonsupplemented babies. Mean net retention rate of $\mathrm{Na}^{+}$in group $B$ babies reached 1 $\mathrm{mEq} / \mathrm{kg} / 24 \mathrm{hr}$ during the second balance but declined thereafter, whereas it rose steadily in group $A$ babies.

There was no significant change in urinary $\mathrm{K}^{+}$output with age and excretion rates were similar in groups $A$ and $B$. Fecal $\mathrm{K}^{+}$

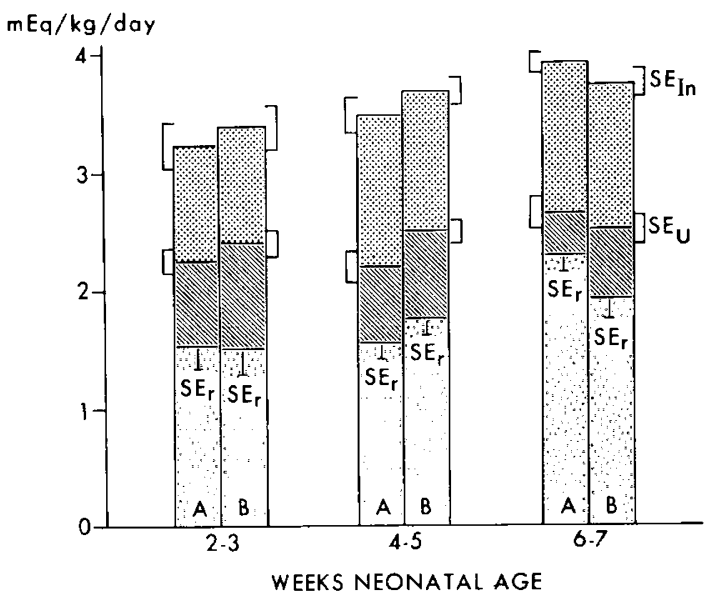

Fig. 3. Potassium intake and output (in milliequivalents per $\mathrm{kg}$ per 24 hr). take is plotted upwards from baseline; $S E_{I n}$ : \pm standard error of intake. : urinary $\mathrm{K}^{+}$excretion, $S E_{U}: \pm \mathrm{SE}$ of urine. $\mathbb{N}$ : fecal $\mathrm{K}^{+}$excretion. : net $\mathrm{K}^{+}$retention, $S E_{r}$ : $-\mathrm{SE}$ of net retention. None of the differences is statistically significant between groups.

excretion was also similar in AGA and SGA babies (average 15\% of intake). Net retention of $\mathrm{K}^{+}$did not change with age and did not differ between groups $A$ and $B$.

\section{CLINICAL FEATURES}

All but 1 of the 39 episodes of mild hyponatremia developed while the infants were clinically well. Two infants, one normonatremic and one mildly hyponatremic, had severe apneic spells. Of the seven patients with plasma $\mathrm{Na}^{+}$values between 120 and 124 $\mathrm{mEq} /$ liter, five were asymptomatic and well, one had apneic spells, and another one had pulmonary edema due to a patent ductus arteriosus. One infant convulsed while moderately hyponatremic, but she had previously had several generalized convulsions when her plasma $\mathrm{Na}^{+}$was normal. Of the four patients with severe hyponatremia (plasma $\mathrm{Na}^{+}<120 \mathrm{mEq} /$ liter), two were asymptomatic, two were lethargic, and one also had severe apneic spells. There was no clinical evidence of extracellular fluid volume contraction or expansion.

When AGA infants were hyponatremic they showed a higher incidence of reduced growth in length $(<1.0 \mathrm{~cm} /$ week $)$ than when plasma $\mathrm{Na}^{+}$was above $130 \mathrm{mEq} /$ liter $(50 \%$ vs $13.5 \% ; P<0.01)$. There was a similar trend of reduced growth in length in SGA infants during hyponatremia, but the relationship was not significant $(64 \%$ vs $40 \% ; P<0.20)$.

\section{DISCUSSION}

Severe hyponatremia (plasma $\mathrm{Na}^{+}<120 \mathrm{mEq} /$ liter) developed in 4 of $17 \mathrm{AGA}$ and 1 of $13 \mathrm{SGA}$ infants; mild episodes of hyponatremia (plasma $\mathrm{Na}^{+} 125-129 \mathrm{mEq}$ /liter) occurred in almost all other AGA babies, usually at 2-6 weeks of age. Most of the patients remained clinically well, but length gain ceased temporarily in some.

Occasional instances of significant hyponatremia in the VLBW occurring after the immediate neonatal period have been reported by Sulyok (20) and Honour et al. (8). Others who reported sequential plasma electrolyte concentrations in prematures did not observe any abnormalities $(19,21)$, but plasma sodium concentrations before 14 days of age were higher than between 15 and 28 days. These reports included only a few infants in the birthweight range examined in our study.

Contributory factors to hyponatremia investigated in this study include inadequate intake, increased losses of $\mathrm{Na}$, and water retention. 
Insufficient intake of sodium as a result of low $\mathrm{Na}^{+}$concentrations in the formula could have contributed to the hyponatremia. According to the findings of Shaw (16) and Widdowson (25), the intrauterine $\mathrm{Na}^{+}$acquisition rate between weeks 31 and 38 is approximately $1.2 \mathrm{mEq} / \mathrm{kg} / 24 \mathrm{hr}$. This was the postconceptional age of the infants discussed in the present study who received 1.6 $\mathrm{mEq} / \mathrm{kg} / 24 \mathrm{hr}$. A continuing deficit developed, inasmuch as urinary excretion rates were high relative to plasma values. The mean net retention rates at 4-5 weeks of postnatal age were slightly higher than the intrauterine $\mathrm{Na}^{+}$acquisition rate, and this was followed by a gradual return of plasma $\mathrm{Na}^{+}$values to normal. Decreased absorption was not a factor.

With continuing growth, increased amounts of $\mathrm{Na}^{+}$are required not only for maintaining the extracellular $\mathrm{Na}^{+}$concentration but also for coprecipitation with calcium in bone (18). Although calcium-supplemented infants showed better mineralized bones on radiographs (6), the frequency and degree of hyponat remia did not differ between the groups. Sodium precipitation in bone was therefore not a major factor in the development of hyponatremia.

Renal conservation of $\mathrm{Na}^{+}$was inefficient, particularly early in the study when most infants were hyponatremic. The electrolyte pattern in plasma (hyponatremia and hyperkalemia) and urine was similar to that reported by Sulyok (20). Hyponatremia and hyperkalemia may occur secondary to hypoaldosteronism, due either to immaturity of the renal tubular $\mathrm{Na}^{+}$reabsorptive mechanism in the VLBW related to immaturity of the renin-angiotensin-aldosterone system or to renal tubular unresponsiveness to aldosterone (pseudohypoaldosteronism) $(13,14)$. During the first week of life in infants of any gestational age the size of the extracellular fluid compartment decreases and urinary excretion rates of $\mathrm{Na}^{+}$are high. This relatively high urinary sodium excretion rate seems to be protracted in premature infants as described by Kerpel-Fronius et al. (10) and Sulyok (20). These investigators found, as we did, a gradual reduction of urinary $\mathrm{Na}^{+}$ excretion rates after the age of 4-5 weeks.

High serum and urinary aldosterone values have been reported both in premature and full term infants $(3,8,11-13,17,24)$. Primary hypoaldosteronism, therefore, is unlikely to have been a major factor. Renal tubular unresponsiveness to aldosterone, producing a state of pseudohypoaldosteronism, may coexist with normal or elevated plasma aldosterone levels $(13,14)$ and cannot be excluded. We did not measure aldosterone secretion rates in these tiny infants, but in several babies plasma $\left[\mathrm{K}^{+}\right\rfloor$after treatment with $\mathrm{Na}^{+}$decreased significantly to normal values.

It is said that there is a direct relationship between renal tubular reabsorption of calcium and sodium; increased urinary calcium excretion is usually associated with increased losses of sodium in the urine and vice versa $(23,26)$. Thus, the increased calcium intake in infants of group $B$ which might have resulted in hypercalciuria may have contributed to the high urinary losses of $\mathrm{Na}^{+}$. However, $\mathrm{Na}^{+}$excretion was highest in the first balance before calcium supplementation had started and no significant differences occurred in urinary calcium excretion between groups.

Of the possible routes of $\mathrm{Na}^{+}$loss, emesis was not a problem nor was fecal loss excessive. Sweat $\mathrm{Na}^{+}$was not measured since very premature infants do not usually sweat (4). Furthermore, the babies included in the study were maintained in a strictly controlled thermal environment in a humidified atmosphere.

Hyperkalemia was particularly frequent in AGA infants. High mean plasma $\mathrm{K}^{+}$values have been observed in both premature and full term neonates $(1,9,20,22)$. In the premature infant with respiratory distress syndrome, Usher (22) attributed the hyperkalemia to acidosis resulting in altered distribution of $\mathrm{K}^{+}$between plasma and erythrocytes and other cells.

The majority of infants had no clinical edema and weight gain was relatively steady from day $2 I$ onwards. Measurement of total body water (antipyrine space) and extracellular fluid (bromide space) in a subsequent study has failed to show any expansion of these body spaces (15). Thus, there seems little evidence of dilutional hyponatremia.

\section{SUMMARY}

Hyponatremia (plasma $\mathrm{Na}^{+}<130 \mathrm{mEq} /$ liter) occurred frequently in $<1.3 \mathrm{~kg}$ VLBW infants between the ages of 3 and 6 weeks, and was not affected by calcium supplementation. Hyperkalemia (plasma $\mathrm{K}^{+}>5.5 \mathrm{mEq} /$ liter) also occurred commonly in these babies, particularly in AGA infants. Although there was no direct correlation between these two electrolyte abnormalities, elevated plasma $\mathrm{K}^{+}$values decreased when hyponatremia was corrected. It was found that high urinary losses of $\mathrm{Na}^{+}$relative to the plasma $\mathrm{Na}^{+}$concentration, as well as insufficient intake because of the relatively low $\mathrm{Na}^{+}$content of the diet, contributed to the development of hyponatremia. Coprecipitation of $\mathrm{Na}^{+}$in bone at times of rapid length growth also may have been an additional factor in the development of this electrolyte abnormality. The prolonged feeding of relatively low sodium formula initially exceeded the renal compensatory mechanisms for $\mathrm{Na}^{+}$ retention. Balance measurements suggest that $\mathrm{VLBW}$ infants require approximately $3 \mathrm{mEq} / \mathrm{kg} / 24 \mathrm{hr}$ of sodium to achieve normonatremia between the ages of 2 and 5 weeks.

\section{REFERENCES AND NOTES}

1. Acharya, P. T., and Payne, W. W.: Blood chemistry of normal full-term infants in the first 48 hours of life. Arch. Dis. Childhood, 40:430 (1965).

2. Albert, M. S., and Winters, R. W.: Acid-base equilibrium of blood in norma! infants. Pediatrics, 37: 728 (1966).

3. Bayard, F., Ances, I. G., Tapper, A. J., Weldon, V. V., Kowarski, A., and Migeon, C. J.: Transplacental passage and fetal secretion of aldosterone. J. Clin. Invest., 49: 1389 (1970).

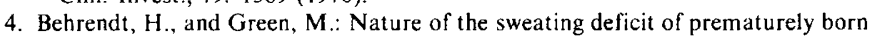
neonates: Observations on babies with the heroin withdrawal syndrome. $\mathrm{N}$. Engl. J. Med., 286: 1376 (1972)

5. Cotlove, E.: Determination of chloride in biological materials. 1n: D. Glick: Methods of Biochemical Analysis, Vol. XII, pp. 277-392 (Interscience Publishers, John Wiley \& Sons, New York, 1964).

6. Day, G. M., Chance, G. W., Radde, I. C., Reilly, B. J., Park, E., and Sheepers, J.: Growth and mineral metabolism in very low birth weight infants. II. Effects of calcium supplementation on growth and divalent cations. Pediat. Res., 9: 568 (1975).

7. Dubowitz, L. M. S., Dubowitz, V., and Goldberg, C.: Clinical assessment of gestational age in the newborn infant. J. Pediat., 77: 1 (1970).

8. Honour, J. W., Shackleton, C. H. L., and Valman, H. B.: Sodium homeostasis in preterm infants. Lancet, ii: 1147 (1974)

9. Keitel, H. G.: The concentration of potassium in the plasma. Amer. J. Dis. Child., 97: 583 (1959)

10. Kerpel-Fronius, E., Heim, T., and Sulyok, E.: The development of the renal acidifying processes and their relation to acidosis in low birth-weight infants. Biol. Neonate, 15: 156 (1970).

11. Kotchen, T. A., Strickland, A. L., Rice, T. W., and Walters, D. R.: A study of the renin-angiotensin system in newborn infants. J. Pediat., $80: 938$ (1972).

12. Mott, J. C.: The place of the renin-angiotensin system before and after birth. Brit. Med. Bull., 31: 44 (1975).

13. Proesmans, W., Geussens, I1., Corbeel, L., and Eeckels, R.: Pseudoaldosteronism. Amer. J. Dis. Child., 126: 510 (1973).

14. Rösler, A., Gazit, E., Theodor, R., Biochis, H., and Rabinowitz, D.: Salt wastage, raised plasma-renin activity, and normal or high plasma-aldosterone: A form of pseudoaldosteronism. Lancet, $i$ : 959 (1973).

15. Roy, R. N., Chance, G. W., Radde, I. C., Hill, D. E., Willis, D. M., and Sheepers, J.: Late hyponatremia in very low birthweight (VLBW) infants $(<1.3$ kg). Pediat. Res., 10: 526 (1976).

16. Shaw, J. C. L.: Parenteral nutrition in the management of sick low birth weight infants. Pediat. Clin. N. Amer. 20: 333 (1973).

17. Siegel, S. R., Fisher, D. A., and Oh, W.: Serum aldosterone concentrations related to sodium balance in the newborn infant. Pediatrics, 53: 410 (1974).

18. Sinclair, J. C., Driscoll, J. M., Heird, W. C., and Winters, R. W.: Supportive management of the sick neonate: Parenteral calories, water, and electrolytes. Pediat. Clin. N. Amer, 17: 863 (1970).

19. Ströder, J., and Zeisel, H.: Einfluss von Nahrungen unterschiedlicher Zusammensetzung auf chemische, immunologische sowie Gerinnungsparameter des Blutes Frühgeborener. Z. Kinderheilk., 111: 1 (1971).

20. Sulyok, E.: The relationship between electrolyte and acid-base balance in the premature infant during early postnatal life. Biol. Neonate, 17: 227 (1971).

21. Thomas, J. L., and Reichelderfer, T. E.: Premature infants: Analysis of serum during the first seven weeks. Clin. Chem., 14: 272 (1968).

22. Usher, R.: The respiratory distress syndrome of prematurity. 1. Changes in potassium in the serum and the electrocardiogram and effects of therapy. Pediatrics, 24: 562 (1959)

23. Walser, M.: Calcium clearance as a function of sodium clearance in the dog. Amer. J. Physiol., 200: 1099 (1961).

24. Weldon, V. V., Kowarski, A., and Migeon, C. J.: Aldosterone secretion rates in 
normal subjects from infancy to adulthood. Pediatrics, 39: 713 (1967).

25. Widdowson, E. M.: The fetus and neonate. In: N. S. Assali: Biology of Gestation Vol. II (Academic Press, New York, 1968).

26. Wills, M. R., Gill, J. R., Jr., and Bartter, F. C.: The interrelationships of calcium and sodium excretion. Clin. Sci., 37: 621 (1969).

27. SMA S26, Wyeth, Ltd., 4455 Chesswood Drive, P.O. Box 10, Downsview, 461 Ont. Manufacturer's composition of formula when reconstituted to $80 \mathrm{cal} / \mathrm{dl}$ is: fat $4.3 \%$, carbohydrate $8.6 \%$, protein $1.8 \%, \mathrm{Na}^{+} 0.84 \mathrm{mEq} / \mathrm{dl}, \mathrm{K}^{+} 1.90$ $\mathrm{mEq} / \mathrm{dl}, \mathrm{Cl} 1.32 \mathrm{mEq} / \mathrm{dl}$

28. ABDEC, Parke Davis \& Co., Ltd., 350 Evans Avenue, Toronto 18, Ont

29. Unicam SP 1900 Atomic absorption flame spectrophotometer, Pye Unicam, York St., Cambridge, CBI 2PX, England.
30. The authors wish to thank Miss A. Zitman, R.N., for her assistance in specimen collection, recording of clinical data, and supervision of balance studies; Mrs. D. Hanimyan, B.Sc., Mr. J. Fabenyi, R.T., B.Agr., and Mrs. P. Thorpe, R.T. for their expert technical assistance. The authors are grateful to the Medical and Nursing Staff of the Neonatal Unit of the Hospital for Sick Children for their help and cooperation.

31. This investigation was supported in part by the Medical Research Council of Canada (Grant no. MA 4635).

32. Requests for reprints should be addressed to: I. C. Radde, M.D., Research Institute, The Hospital for Sick Children, 555 University Ave., Toronto, Ontario M5G IX8 (Canada).

33. Accepted for publication August 15, 1975

\title{
Late Hyponatremia in Very Low Birthweight Infants $(<1.3$ Kilograms)
}

\author{
R. NEIL ROY, G. W. CHANCE, I. C. RADDE, ${ }^{(30)}$ D. E. HILL, D. M. WILLIS, AND J. SHEEPERS \\ Research Institute, Divisions of Neonatology and Endocrinology, The Hospital for Sick Children; Department of \\ Paediatrics, University of Toronto, Toronto, Ontario, Canada
}

\section{Extract}

Late hyponatremia (plasma $\mathrm{Na}^{+}<130 \mathrm{mEq} /$ liter) occurred frequently (on 54 of 159 occasions) in 46 very low birthweight (VLBW) infants $(<1.3 \mathrm{~kg}$ at birth) between 2 and 6 weeks of age while receiving a sodium intake of $\leq 2 \mathrm{mEq} / \mathrm{kg} / 24 \mathrm{hr}$. To elucidate possible pathogenetic mechanisms five groups of such infants were studied while receiving a commercially available formula reconstituted to give two different volumes and two different $\mathrm{Na}^{+}$concentrations. Sodium intake in the nonsupplemented (NS) infants $(n=$ 23) was less than $2 \mathrm{mEq} / \mathrm{kg} / 24 \mathrm{hr}$. Supplemented (S) infants $(n=$ 16) received approximately $3 \mathrm{mEq} \mathrm{Na}{ }^{+} / \mathrm{kg} / 24 \mathrm{hr}$. A further group of seven infants given a high volume $(200 \mathrm{ml} / \mathrm{kg} / 24 \mathrm{hr})$, high caloric $\left(100 \mathrm{cal} / \mathrm{dl}\right.$ ) formula and $\mathrm{Na}^{+}$supplementation $($to $3 \mathrm{mEq} / \mathrm{kg} / 24 \mathrm{hr}$ ) was also included. Infants were studied from age 14 days until they weighed $1.80 \pm 0.05 \mathrm{~kg}$ at a mean age of 47 days.

At the time of start of the study, 6 of 20 NS and 6 of $19 \mathrm{~S}$ infants were hyponatremic. After supplementation only two episodes of hyponatremia occurred in $S$ infants, both during the first study week, whereas the high incidence of hyponatremia in NS infants remained unchanged throughout the first 3 weeks of the study period.

During baseline urine collections all infants excreted between 80 and $100 \mathrm{ml} / \mathrm{kg} / 24 \mathrm{hr}$ urine, but those receiving $150 \mathrm{ml} / \mathrm{kg} / 24 \mathrm{hr}$ formula decreased their urinary output rapidly to $50 \mathrm{ml} / \mathrm{kg} / 24 \mathrm{hr}$, whereas infants receiving high volume feeds $(200 \mathrm{ml} / \mathrm{kg} / 24 \mathrm{hr})$ did not decrease their urinary output until the third balance at an average age of 45 days. All infants excreted between 1.0 and 1.2 $\mathrm{mEq} / \mathrm{kg} / 24 \mathrm{hr}$ of sodium in their urine during the initial collection. Nonsupplemented infants reduced their urinary $\mathrm{Na}^{+}$excretion more rapidly than supplemented babies (NS: from 1.03 to $0.55 \mathrm{mEq}$ / $\mathrm{kg} / 24 \mathrm{hr}$, first $v s$ second balance; $\mathrm{S}$ : from 1.00 to $0.80 \mathrm{mEq} / \mathrm{kg} / 24$ $\mathrm{hr}$, first $v s$ third balance). Mean potassium excretion remained unchanged in NS and $S$ infants during the study period and was not affected by the volume or caloric content of the formula.

Extracellular volume (ECV) and total body water (TBW) were measured serially, and there were no differences between $S$ and NS infants in the distribution of body water. The percentage of TBW and ECV decreased in all groups with increasing postnatal age.

\section{Speculation}

VLBW infants are prone to hyponatremia in the first 6 weeks of life because of the combined influence of renal immaturity, which permits relatively high urinary sodium loss in the presence of low plasma $\left[\mathrm{Na}^{+}\right]$, and low intake of sodium $(\leq 2 \mathrm{mEq} / \mathrm{kg} / 24 \mathrm{hr})$, the amount provided by some current formulas based on breast milk. Dilutional factors are not involved, but the role of aldosterone remains unresolved. Supplementation of the formula to provide a daily total sodium intake of $3 \mathrm{mEq} / \mathrm{kg} / 24 \mathrm{hr}$ until a weight of $1.5 \mathrm{~kg}$ is reached is corrective.

Investigations into the nutritional requirements for the VLBW infant $(<1.3 \mathrm{~kg})$ are being carried out in several phases in the Hospital for Sick Children, Toronto. During earlier investigations of calcium supplementation (7), a frequent incidental finding was a low plasma sodium concentration at 2-7 weeks postnatal age (8). The present study was designed to determine in VLBW infants the appropriate $\mathrm{Na}^{+}$intake to prevent this hyponatremia and to investigate possible underlying factors. We examined the effect of differences in feed volume and $\mathrm{Na}^{+}$and caloric intakes on plasma and urinary electrolytes and on body fluid compartments.

\section{PATIENTS, PROCEDURES, AND METHODS}

\section{PATIENTS}

Forty-six infants of birthweight $<1.3 \mathrm{~kg}$ were studied. Table I shows the study groups, their mean birthweight, and their gestational age. All infants $<1.3 \mathrm{~kg}$ birthweight admitted to the Neonatal Unit of the Hospital for Sick Children, Toronto, were 